\title{
PREVALENCE OF RHEUMATOID ARTHRITIS
}

\author{
BY \\ J. S. LAWRENCE \\ From the Empire Rheumatism Council Field Unit, based on the University of Manchester
}

In 1956, a committee of the American Rheumatism Association was formed to investigate diagnostic criteria for rheumatoid arthritis. They recommended that the disease should be classified into three categories: definite, probable, and possible, the classification being based on a points system.

The eleven points used for this classification included symptoms, physical signs, radiographic appearances, and laboratory tests (Ropes, Bennett, Cobb, Jacox, and Jessar, 1956, 1957, 1959). Though possessing certain limitations, particularly in relation to population studies in which the results of histological and synovial fluid examination are seldom available, these criteria do offer certain theoretical advantages over a simple clinical grading for rheumatoid arthritis. It was felt, therefore, that the publication of data on the American Rheumatism Association criteria in population samples drawn from an urban and a rural area in England might be of value to research workers in this country who desired a standard for comparison with their own findings.

\section{Methods of Survey}

The data used in this paper are drawn from two surveys: one in Leigh, Lancashire, based on a 1 in 30 random sample of persons aged 15 and over (Lawrence and Bennett, 1960); the other in Wensleydale, in the North Riding of Yorkshire, based on an area sample, including half the town of Hawes and half the villages in the area with their surrounding farms. In the Leigh sample there were 751 males and 814 females, in the Wensleydale sample 485 males and 540 females. Thus there was a total of 1,236 males and 1,354 females in the combined sample of whom 1,060 and 1,174 respectively were actually examined. The age and sex distribution was similar in these two areas and the completion rate (proportion of available persons having $x$ rays or a blood test or both) was also alike (86 per cent. in Leigh and 87 per cent. in Wensleydale). The clinical, radiological, and serological examination was based on the same routine procedure in Wensleydale and in L.eigh, all persons having $x$ rays of the hands, feet, and cervical spine. All $x$ rays of the cervical spine were read by at least two observers. The sheep cell agglutination test was carried out by the method of Ball (1950).

American Rheumatism Association Criteria.-In assessing the American Rheumatism Association criteria, the clinical and radiographic criteria and the sheep cell agglutination test were used. Of the $x$-ray findings, only changes present in the hands and feet were included in the assessment.

\section{Prevalence in Mixed Urban-Rural Population}

"Definite"* rheumatoid arthritis was encountered in five males and nineteen females, "probable" disease in 21 and 52, and "possible" in 73 and 132 (Table I, overleaf).

If those falling into the "probable" and "definite" categories are accepted as having rheumatoid arthritis, the minimal prevalence (expressed as a proportion of the total in the sample) is $2 \cdot 1$ per cent. in males and 5.2 per cent. in females. In assessing the minimal prevalence it was assumed that none of those who were not examined had rheumatoid arthritis. The mean prevalence (expressed as a proportion of the total examined) was 2.5 per cent. in males and 6.0 per cent. in females. The true value must lie somewhere between these figures, since those who refuse to co-operate are generally persons without rheumatic symptoms.

The prevalence of "probable" and "definite"

" "Classical" rheumatoid arthritis has been included in the "definite" group. 
TABLE I

AMERICAN RHEUMATISM ASSOCIATION CRITERIA APPLIED TO THE COMBINED

LEIGH AND WENSLEYDALE POPULATIONS

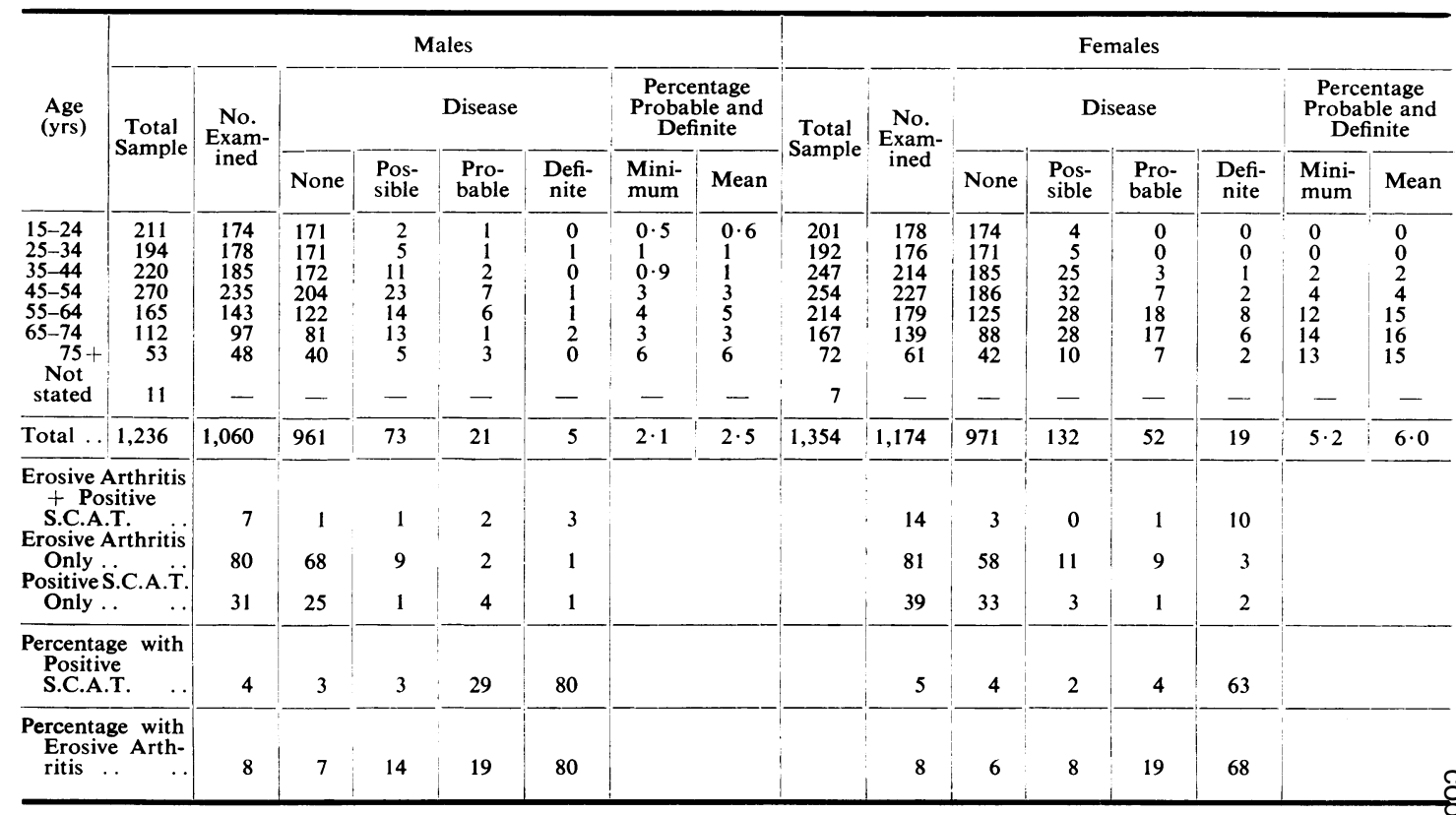

disease rose with age in both sexes, reaching a maximum of 6 per cent. in males aged 75 and over and 16 per cent. in females aged 65 to 74 years. The disease appeared at a rather earlier age in males, no females having "probable" or "definite" disease before age 35 .

The proportion of positive sheep cell agglutination tests in the combined Leigh and Wensleydale populations was 4 per cent. in males and 5 per cent. in females. The sheep cell titre distribution in the Leigh and Wensleydale populations is to be discussed in detail in a further communication (Ball and Lawrence, 1961).

A positive sheep cell agglutination test was found in four of the five males with "definite" disease and in twelve of the nineteen females. Thus in 67 per cent. of "definite" cases the test was positive. Of the 21 males with "probable" disease, six (29 per cent.) had a positive sheep cell agglutination test, but of the 52 females with "probable" disease only two (4 per cent.) had a positive test. Those with "possible" disease had no more positive tests than those with "no" disease.

Radiological evidence of erosive arthritis was encountered in four ( 80 per cent.) of the five males with "definite" disease and in thirteen (68 per cent.) of the nineteen females. Evidence of erosive arthritis was seen in 19 per cent. of both males and females with "probable" disease, in 14 and 8 per cent. respectively of those with "possible" disease, and in 7 and 6 per cent. respectively of those with "no" disease. The American Rheumatism Association criteria were thus found to be correlated with both the $x$-ray changes and the sheep cell test in both sexes.

Of the 1,042 males who were $x$-rayed, 87 ( 8 per cent.) had radiological evidence of erosive arthritis, and of the 1,157 females also 8 per cent. (Table II, opposite).

The proportion was thus the same in males and females and confirms earlier findings in population samples (Kellgren and Lawrence, 1956; Miall, Ball, and Kellgren, 1958). As indicated by the American Rheumatism Association criteria, the prevalence increased with age. In the 15- to 24-year group none of the males and only 1 per cent. of the females showed definite changes. In males aged 75 and over, on the other hand, 34 per cent. were considered to have definite evidence of erosive arthritis and the proportion was similar in females. Radiological changes were encountered most commonly in the cervical spine, the grading at this site 
TABLE II

RADIOLOGICAL EROSIVE ARTHRITIS (ALL SITES) IN LEIGH AND WENSLEYDALE, BY AGE AND SEX (Gradings based on the Readings OF ONe ObSERVER)

\begin{tabular}{|c|c|c|c|c|c|c|c|c|c|c|c|c|c|c|}
\hline \multirow{3}{*}{$\begin{array}{l}\text { Age } \\
\text { (yrs) }\end{array}$} & \multicolumn{7}{|c|}{ Males } & \multicolumn{7}{|c|}{ Females } \\
\hline & \multirow{2}{*}{$\underset{X \text {-rayed }}{\text { Total }}$} & \multicolumn{6}{|c|}{ Grade } & \multirow{2}{*}{$\underset{X \text {-rayed }}{\text { Total }}$} & \multicolumn{6}{|c|}{ Grade } \\
\hline & & 0 & 1 & 2 & 3 & 4 & $\begin{array}{l}\text { Percentage } \\
2 \text { to } 4\end{array}$ & & 0 & 1 & 2 & 3 & 4 & $\begin{array}{c}\text { Percentage } \\
2 \text { to } 4\end{array}$ \\
\hline $\begin{array}{r}15-24 \\
25-34 \\
35-44 \\
45-54 \\
55-64 \\
65-74 \\
75+\end{array}$ & $\begin{array}{r}165 \\
177 \\
184 \\
234 \\
141 \\
94 \\
47\end{array}$ & $\begin{array}{r}133 \\
143 \\
123 \\
126 \\
72 \\
25 \\
10\end{array}$ & $\begin{array}{l}32 \\
32 \\
55 \\
91 \\
50 \\
42 \\
21\end{array}$ & $\begin{array}{r}0 \\
1 \\
6 \\
16 \\
17 \\
21 \\
12\end{array}$ & $\begin{array}{l}0 \\
1 \\
0 \\
0 \\
1 \\
6 \\
3\end{array}$ & $\begin{array}{l}0 \\
0 \\
0 \\
0 \\
1 \\
1 \\
0 \\
1\end{array}$ & $\begin{array}{r}-1 \\
4 \\
7 \\
14 \\
30 \\
34\end{array}$ & $\begin{array}{r}172 \\
173 \\
214 \\
226 \\
178 \\
137 \\
57\end{array}$ & $\begin{array}{r}140 \\
147 \\
150 \\
139 \\
90 \\
32 \\
10\end{array}$ & $\begin{array}{l}30 \\
24 \\
62 \\
75 \\
65 \\
70 \\
28\end{array}$ & $\begin{array}{r}2 \\
2 \\
1 \\
11 \\
17 \\
26 \\
14\end{array}$ & $\begin{array}{l}0 \\
0 \\
0 \\
1 \\
4 \\
8 \\
1\end{array}$ & $\begin{array}{l}0 \\
0 \\
1 \\
0 \\
2 \\
1 \\
4\end{array}$ & $\begin{array}{l}1 \\
1 \\
0 \cdot 9 \\
5 \\
13 \\
30 \\
33\end{array}$ \\
\hline Total & 1,042 & 632 & 323 & 73 & 11 & 3 & 8 & 1,157 & 708 & 354 & 73 & 14 & 8 & 8 \\
\hline
\end{tabular}

TABLE III

RADIOLOGICAL EROSIVE ARTHRITIS OF THE CERVICAL SPINE IN LEIGH AND WENSLEYDALE, BY AGE AND SEX (Gradings Based on the Readings of Two or THReE Observers)

\begin{tabular}{|c|c|c|c|c|c|c|c|c|c|c|c|c|}
\hline \multirow{3}{*}{$\begin{array}{c}\text { Age } \\
\text { (yrs) }\end{array}$} & \multicolumn{6}{|c|}{ Males } & \multicolumn{6}{|c|}{ Females } \\
\hline & \multirow{2}{*}{$\underset{X \text {-rayed }}{\text { Total }}$} & \multicolumn{5}{|c|}{ Grade } & \multirow{2}{*}{$\begin{array}{c}\text { Total } \\
X \text {-rayed }\end{array}$} & \multicolumn{5}{|c|}{ Grade } \\
\hline & & 0 & 1 & 2 & 3 to 4 & $\begin{array}{l}\text { Percentage } \\
2 \text { to } 4\end{array}$ & & 0 & 1 & 2 & 3 to 4 & $\begin{array}{l}\text { Percentage } \\
2 \text { to } 4\end{array}$ \\
\hline $\begin{array}{c}15-24 \\
25-34 \\
35-44 \\
45-54 \\
55-64 \\
65-74 \\
75+\end{array}$ & $\begin{array}{r}165 \\
176 \\
183 \\
233 \\
139 \\
93 \\
47\end{array}$ & $\begin{array}{r}146 \\
157 \\
162 \\
182 \\
101 \\
36 \\
19\end{array}$ & $\begin{array}{l}19 \\
19 \\
20 \\
45 \\
27 \\
39 \\
15\end{array}$ & $\begin{array}{r}0 \\
0 \\
1 \\
6 \\
10 \\
15 \\
9\end{array}$ & $\begin{array}{l}0 \\
0 \\
0 \\
0 \\
1 \\
3 \\
4\end{array}$ & $\begin{array}{c}\overline{7} \\
\overline{0} \cdot 5 \\
3 \\
8 \\
19 \\
28\end{array}$ & $\begin{array}{l}170 \\
172 \\
213 \\
224 \\
174 \\
137 \\
57\end{array}$ & $\begin{array}{r}156 \\
163 \\
194 \\
189 \\
119 \\
76 \\
21\end{array}$ & $\begin{array}{l}12 \\
9 \\
18 \\
27 \\
44 \\
34 \\
24\end{array}$ & $\begin{array}{r}2 \\
0 \\
0 \\
7 \\
8 \\
21 \\
12\end{array}$ & $\begin{array}{l}0 \\
0 \\
1 \\
1 \\
3 \\
6 \\
0\end{array}$ & $\begin{array}{l}1 \\
0 \\
0 \cdot 5 \\
4 \\
6 \\
20 \\
21\end{array}$ \\
\hline Total & 1,036 & 803 & 184 & 41 & 8 & 5 & 1,147 & 918 & 168 & 50 & 11 & 5 \\
\hline
\end{tabular}

being made by the criteria of Sharp, Purser, and Lawrence (1958). An average of the readings of two to three observers was used for Table III (above). The prevalence of rheumatoid arthritis by these criteria was 5 per cent. in both sexes, rising to 28 per cent. in males and 21 per cent. in females aged 75 and over. In view of the high prevalence of cervical arthritis in those aged 65 and over, it must be considered whether degenerative disease produces a similar picture in old persons. This will be dealt with in a later communication. Erosive arthritis of the hands or feet (Table IV) was encountered in only 3 per cent. of both males and females, and was not found at all below age 25 in males or age 35 in females. Severe changes in hands and feet were seen in two males and six females.

TABLE IV

RADIOLOGICAL EROSIVE ARTHRITIS OF THE HANDS AND FEET IN LEIGH AND WENSLEYDALE, BY AGE AND SEX (Gradings Based on the REAdings of ONE ObSERVER)

\begin{tabular}{|c|c|c|c|c|c|c|c|c|c|c|c|c|c|c|}
\hline \multirow{3}{*}{$\begin{array}{c}\text { Age } \\
\text { (yrs) }\end{array}$} & \multicolumn{7}{|c|}{ Males } & \multicolumn{7}{|c|}{ Females } \\
\hline & \multirow{2}{*}{$\underset{X \text {-rayed }}{\text { Total }}$} & \multicolumn{6}{|c|}{ Grade } & \multirow{2}{*}{$\underset{X \text {-rayed }}{\text { Total }}$} & \multicolumn{6}{|c|}{ Grade } \\
\hline & & 0 & 1 & 2 & 3 & 4 & $\begin{array}{l}\text { Percentage } \\
2 \text { to } 4\end{array}$ & & 0 & 1 & 2 & 3 & 4 & $\begin{array}{l}\text { Percentage } \\
2 \text { to } 4\end{array}$ \\
\hline $\begin{array}{c}15-24 \\
25-34 \\
35-44 \\
45-54 \\
55-64 \\
65-74 \\
75+\end{array}$ & $\begin{array}{r}165 \\
177 \\
184 \\
234 \\
141 \\
94 \\
47\end{array}$ & $\begin{array}{r}160 \\
169 \\
173 \\
190 \\
120 \\
64 \\
28\end{array}$ & $\begin{array}{r}5 \\
7 \\
9 \\
35 \\
14 \\
22 \\
15\end{array}$ & $\begin{array}{l}0 \\
0 \\
2 \\
8 \\
5 \\
6 \\
3\end{array}$ & $\begin{array}{l}0 \\
1 \\
0 \\
0 \\
1 \\
2 \\
1\end{array}$ & $\begin{array}{l}0 \\
0 \\
0 \\
1 \\
1 \\
0 \\
0\end{array}$ & $\begin{array}{l}-\overline{0} \cdot 6 \\
1 \\
4 \\
5 \\
9 \\
9\end{array}$ & $\begin{array}{r}172 \\
174 \\
214 \\
226 \\
178 \\
137 \\
57\end{array}$ & $\begin{array}{r}163 \\
168 \\
200 \\
201 \\
149 \\
76 \\
32\end{array}$ & $\begin{array}{r}9 \\
6 \\
13 \\
24 \\
21 \\
46 \\
16\end{array}$ & $\begin{array}{r}0 \\
0 \\
0 \\
1 \\
4 \\
14 \\
5\end{array}$ & $\begin{array}{l}0 \\
0 \\
0 \\
0 \\
2 \\
1 \\
1\end{array}$ & $\begin{array}{l}0 \\
0 \\
1 \\
0 \\
2 \\
0 \\
3\end{array}$ & $\begin{array}{l}- \\
\overline{0} \cdot 5 \\
0 \cdot 4 \\
4 \\
11 \\
16\end{array}$ \\
\hline Total & 1,042 & 904 & 107 & 24 & 5 & 2 & 3 & 1,158 & 989 & 135 & 24 & 4 & 6 & 3 \\
\hline
\end{tabular}


Comparison of American Rheumatism Association Criteria with Other Classifications of Inflammatory Polyarthritis

(1) Manchester Gradings.-During the surveys in Leigh and Wensleydale each respondent was graded for severity of inflammatory polyarthritis on a 0-4 scale. The gradings for each age group and the prevalences of Grades 2 to 4 (minimal, moderate, and severe) are shown in Table V. Grade 2 to 4 arthritis by this Manchester grading was found slightly more often in both males and females than the categories "probable" and "definite" by the American Rheumatism Association criteria, but the difference in prevalence was very slight, amounting to only 0.3 per cent. in males and 0.2 per cent. in females. The main differences between the two methods of grading are found in the females, the younger females appearing to have more arthritis by the Manchester scale, and the older females more by the American Rheumatism Association criteria. In the 25- to 34-year age group, for example, there were four females with arthritis by the Manchester scale and none by the American Rheumatism Association criteria. Of the four females concerned, three had "possible" rheumatoid arthritis and the fourth had a history of stiffness and swelling of the fingers lasting only 3 days which did not qualify her for the "possible" grade. However, this stiffness in the fingers was later followed by persistent subjective stiffness of the knees. It would thus appear that certain mild forms of polyarthritis in young females are not included in the "probable" or "definite" grades of the American Rheumatism Association criteria and may also fail to be included in the "possible" group. The four females mentioned above all had a negative sheep cell agglutination test and lacked radiological erosions.

Of the 23 "probables" or "definites" in the 65- to 74-year age group in females, only thirteen had Grade 2 to 4 rheumatoid arthritis by the Manchester standard. Of the remaining ten, six had been given a doubtful grading for rheumatoid arthritis at the time and the remaining four had been diagnosed as generalized osteo-arthrosis or osteo-arthrosis of the knees. Thus, in the older females, a proportion of those with osteo-arthrosis fall into the "probable" and "definite" group.

A comparison of the American Rheumatism Association criteria with the clinical grading for rheumatoid arthritis in Leigh is shown diagramatically in the Figure (opposite), comparison being made with the clinical grading in an earlier survey of rheumatic complaints made in Leigh in 1950 (Kellgren, Lawrence, and Aitken-Swan, 1953). The two clinical gradings are in general closer to one another than are the American Rheumatism Association criteria to either.

(2) Miall's Criteria.-Miall and others (1958) assessed the prevalence of rheumatoid arthritis in South Wales. The criteria used for rheumatoid arthritis were a history of painful swellings of the hands or feet, with $x$-ray evidence of erosive arthritis in the hands or feet or a positive sheep cell agglutina tion test. The prevalence in random samples od persons aged 15 or more in South Wales by these criteria was 1 per cent. in each sex. At age 65 and over the maximum of 4 per cent. was attained.

When these criteria were applied to the Leigh and Wensleydale population samples (Table VI, opposite), a prevalence of 1 per cent. was found in males and 2 per cent. in females. Thus, by these criteria, the prevalence is about one-third of that estimated by the American Rheumatism Association criteria or the Manchester diagnostic grading. In the older age groups, where objective criteria are found in a

TABLE V

MANCHESTER CLINICAL GRADINGS FOR INFLAMMATORY POLYARTHRITIS APPLIED TO THE COMBINED LEIGH AND WENSLEYDALE POPULATIONS

\begin{tabular}{|c|c|c|c|c|c|c|c|c|c|c|c|c|c|c|}
\hline \multirow{3}{*}{$\begin{array}{c}\text { Age } \\
\text { (yrs) }\end{array}$} & \multicolumn{7}{|c|}{ Males } & \multicolumn{7}{|c|}{ Females } \\
\hline & \multirow{2}{*}{$\begin{array}{c}\text { Total } \\
\text { Examined }\end{array}$} & \multicolumn{6}{|c|}{ Grade } & \multirow{2}{*}{$\begin{array}{c}\text { Total } \\
\text { Examined }\end{array}$} & \multicolumn{6}{|c|}{ Grade } \\
\hline & & 0 & 1 & 2 & 3 & 4 & $\begin{array}{l}\text { Percentage } \\
2 \text { to } 4\end{array}$ & & 0 & 1 & 2 & 3 & 4 & $\begin{array}{l}\text { Percentage } \\
2 \text { to } 4\end{array}$ \\
\hline $\begin{array}{r}15-24 \\
25-34 \\
35-44 \\
45-54 \\
55-64 \\
65-74 \\
75+\end{array}$ & $\begin{array}{r}174 \\
178 \\
185 \\
235 \\
143 \\
97 \\
48\end{array}$ & $\begin{array}{r}166 \\
163 \\
169 \\
207 \\
131 \\
84 \\
38\end{array}$ & $\begin{array}{r}7 \\
11 \\
12 \\
19 \\
7 \\
10 \\
6\end{array}$ & $\begin{array}{l}1 \\
3 \\
4 \\
6 \\
2 \\
1 \\
2\end{array}$ & $\begin{array}{l}0 \\
1 \\
0 \\
3 \\
2 \\
1 \\
2\end{array}$ & $\begin{array}{l}0 \\
0 \\
0 \\
0 \\
1 \\
1 \\
0\end{array}$ & $\begin{array}{l}0 \cdot 6 \\
2 \\
2 \\
4 \\
3 \\
3 \\
8\end{array}$ & $\begin{array}{r}179 \\
175 \\
214 \\
227 \\
179 \\
139 \\
61\end{array}$ & $\begin{array}{r}165 \\
160 \\
180 \\
177 \\
136 \\
96 \\
42\end{array}$ & $\begin{array}{l}14 \\
11 \\
24 \\
37 \\
24 \\
23 \\
11\end{array}$ & $\begin{array}{r}0 \\
4 \\
9 \\
11 \\
12 \\
16 \\
3\end{array}$ & $\begin{array}{l}0 \\
0 \\
0 \\
2 \\
4 \\
3 \\
3\end{array}$ & $\begin{array}{l}0 \\
0 \\
1 \\
0 \\
3 \\
1 \\
2\end{array}$ & $\begin{array}{r}2 \\
5 \\
6 \\
11 \\
14 \\
13\end{array}$ \\
\hline Total & 1,060 & 958 & 72 & 19 & 9 & 2 & $2 \cdot 8$ & 1,174 & 956 & 134 & 55 & 12 & 7 & $6 \cdot 3$ \\
\hline
\end{tabular}



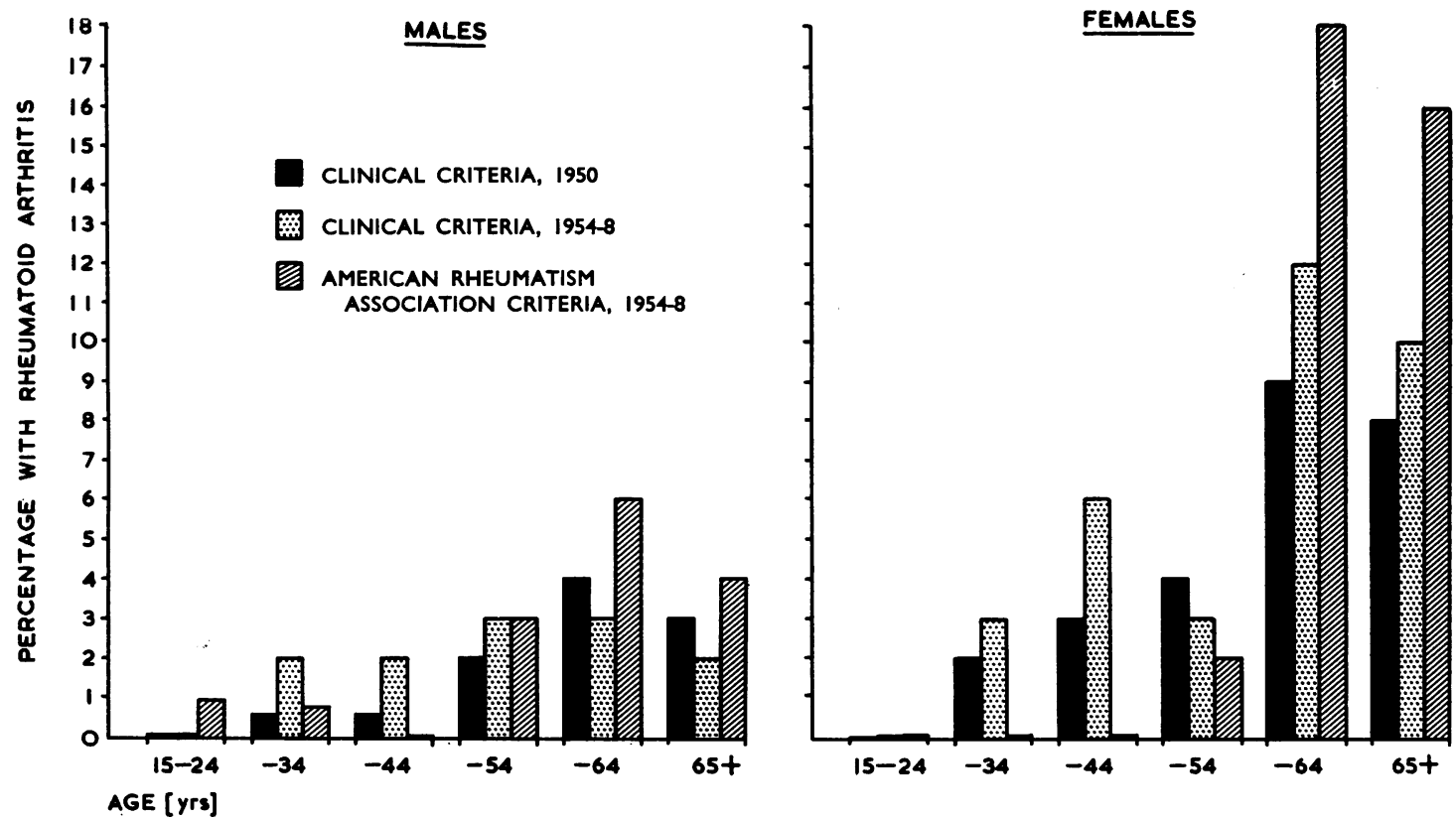

Figure.-Rheumatoid arthritis diagnosed clinically in the 1950 complaints survey and the 1954 to $1958 \mathrm{X}$-ray survey in Leigh, and by the American Rheumatism Association criteria in the latter; this diagram is based on unpublished material. The Wensleydale data have been excluded.

TABLE VI

MIALL'S CRITERIA APPLIED TO THE COMBINED LEIGH AND WENSLEYDALE POPULATIONS

\begin{tabular}{|c|c|c|c|c|c|c|}
\hline \multirow{3}{*}{$\begin{array}{c}\text { Age } \\
\text { (yrs) }\end{array}$} & \multicolumn{3}{|c|}{ Males } & \multicolumn{3}{|c|}{ Females } \\
\hline & \multirow{2}{*}{ Total Tested } & \multicolumn{2}{|c|}{ Confirmed Rheumatoid Arthritis } & \multirow{2}{*}{ Total Tested } & \multicolumn{2}{|c|}{ Confirmed Rheumatoid Arthritis } \\
\hline & & No. & Per cent. & & No. & Per cent. \\
\hline $\begin{array}{r}15-24 \\
25-34 \\
35-44 \\
45-54 \\
55-64 \\
65-74 \\
75+\end{array}$ & $\begin{array}{r}172 \\
172 \\
181 \\
231 \\
138 \\
95 \\
47\end{array}$ & $\begin{array}{l}0 \\
1 \\
0 \\
3 \\
2 \\
3 \\
2\end{array}$ & $\begin{array}{l}\overline{0 \cdot 6} \\
\frac{1}{1} \\
1 \\
3 \\
4\end{array}$ & $\begin{array}{r}180 \\
167 \\
209 \\
215 \\
168 \\
130 \\
58\end{array}$ & $\begin{array}{l}0 \\
0 \\
1 \\
2 \\
7 \\
6 \\
6\end{array}$ & $\begin{array}{c}- \\
\overline{0} \cdot 5 \\
1 \\
4 \\
5 \\
10\end{array}$ \\
\hline Total $\quad \ldots \quad \ldots$ & 1.036 & 11 & $1 \cdot 1$ & 1,123 & 22 & $2 \cdot 0$ \\
\hline
\end{tabular}

high proportion of the population, the difference between Miall's criteria and the other two methods was less striking.

\section{Discussion}

Despite the many factors involved there is considerable agreement on prevalence between the American Rheumatism Association criteria and the Manchester clinical grading. Studies in seven different areas of Northern Europe have not produced evidence of any striking regional differences in prevalence (Lawrence, Laine, and de Graaff, 1961), and it would therefore seem justifiable to apply the figures from Leigh and Wensleydale to the total adult population of Great Britain.

For this purpose the 1958 estimates of the population of England and Wales and the 1959 estimates for Scotland have been used, as these provide the most recent population data available. To avoid exaggerating the importance of this group of diseases, minimal prevalence figures for probable and definite 


\begin{tabular}{|c|c|c|c|c|c|}
\hline \multirow{2}{*}{ Area } & \multirow{2}{*}{$\begin{array}{c}\text { Age } \\
\text { (yrs) }\end{array}$} & \multicolumn{2}{|c|}{ Total in Population } & \multicolumn{2}{|c|}{$\begin{array}{l}\text { Rheumatoid Arthritis } \\
\text { Probable and Definite }\end{array}$} \\
\hline & & Males & Females & Males & Females \\
\hline \multirow[t]{2}{*}{ England and Wales } & $\begin{array}{c}15-24 \\
25-34 \\
35-44 \\
45-54 \\
55-64 \\
65-74 \\
75\end{array}$ & $\begin{array}{r}2,808,000 \\
2,985,000 \\
3,110,000 \\
3,161,000 \\
2,318,000 \\
1,396,000 \\
676,000\end{array}$ & $\begin{array}{l}2,814,000 \\
2,990,000 \\
3,212,000 \\
3,284,000 \\
2,783,000 \\
2,028,000 \\
1,211,000\end{array}$ & $\begin{array}{l}13,308 \\
30,773 \\
28,273 \\
93,659 \\
98,339 \\
37,393 \\
38,262\end{array}$ & $\begin{array}{r}52,016 \\
116,362 \\
336,549 \\
279,305 \\
151,375\end{array}$ \\
\hline & Total aged $15+$ & $16,454,000$ & $18,322,000$ & $\begin{array}{c}340,017 \\
(2 \cdot 1 \text { per cent. })\end{array}$ & $\begin{array}{c}935,607 \\
(5 \cdot 1 \text { per cent. })\end{array}$ \\
\hline \multirow[t]{2}{*}{ Scotland } & $\begin{array}{c}15-24 \\
25-34 \\
35-44 \\
45-54 \\
55-64 \\
65-74 \\
75+\end{array}$ & $\begin{array}{r}348,600 \\
343,700 \\
328,000 \\
335,600 \\
250,000 \\
142,500 \\
71,500\end{array}$ & $\begin{array}{l}366,700 \\
351,100 \\
347,500 \\
358,800 \\
304,100 \\
209,200 \\
115,000\end{array}$ & $\begin{array}{r}1,652 \\
3,543 \\
2,982 \\
9,944 \\
10,606 \\
3,817 \\
4,047\end{array}$ & $\begin{array}{l}5,627 \\
12,713 \\
36,775 \\
28,812 \\
14,375\end{array}$ \\
\hline & Total aged $15+$ & $1,819,900$ & $2,052,400$ & $\begin{array}{c}36,591 \\
(2 \cdot 0 \text { per cent. })\end{array}$ & $\begin{array}{c}98,302 \\
(4 \cdot 8 \text { per cent. })\end{array}$ \\
\hline \multicolumn{2}{|c|}{ Total in United Kingdom aged $15+$} & $18,273,900$ & $20,374,400$ & $\begin{array}{c}376,608 \\
(2 \cdot 1 \text { per cent. })\end{array}$ & $\begin{array}{c}1,033,909 \\
\left(5 \cdot 1_{\text {per cent. }}\right)\end{array}$ \\
\hline
\end{tabular}

disease have been used (Table VII). By this estimate it can be said that at least 377,000 males and $1,034,000$ females in Great Britain had "probable" or "definite" rheumatoid arthritis in 1959.

\section{Summary}

A random sample of 751 males and 814 females in the town of Leigh in Lancashire and an area sample of 485 males and 540 females in Wensleydale in Yorkshire have been investigated clinically, radiologically, and serologically to determine the prevalence of rheumatoid arthritis. The examination was completed in 86 per cent. of the Leigh sample and in 87 per cent. of the Wensleydale sample.

Using the American Rheumatism Association Criteria, the minimal prevalence of "definite" disease was 0.4 per cent. in males and 1.4 per cent. in females, and that of "probable" disease was 1.7 per cent. in males and 3.8 per cent. in females.

Radiological evidence of erosive arthritis was present in 8 per cent. of all those $x$-rayed, both males and females, but the disease was more severe in the females. Changes were most frequently encountered in the cervical spine. A positive sheep cell agglutination test was found in 4 per cent. of males and 5 per cent. of females.

It is estimated that, in Great Britain in 1959, approximately 377,000 males and $1,034,000$ females had "probable" or "definite" rheumatoid arthritis.
All sheep-cell agglutination tests in these population $\vec{\varphi}$ samples were carried out by Dr. J. Ball of the Rheumg- tism Research Centre, Manchester University, to whơ I am indebted for permission to use the results given this paper.

I am also grateful to Prof. J. H. Kellgren, Dr. J. Sharp, and Mr. D. W. Purser for permission to use their $x$-ray $\mathbb{Q}$ readings on the cervical spine, and to Dr. J. Bremner, who carried out the original survey of Wensleydale as a research fellow of the University of Leeds.

\section{REFERENCES}

Ball, J. (1950). Lancet, 2, 520. and Lawrence, J. S. (1961). Ann. rheum. Dis., 20, in preparation.

Kellgren, J. H., and Lawrence, J. S. (1956). Ibid., そ $15,1$.

,-- , and Aitken-Swan, J. (1953). Ibid., 12, 5.

Lawrence, J. S., and Bennett, P. H. (1960). Ibid., $\frac{D}{O}$ 19, 20.

_- Laine, V., and de Graaff, R. (1961). Proc. roy. N Soc. Med. In the press.

Miall, W. E., Ball, J., and Kellgren, J. H. (1958). Ann. N rheum. Dis., 17, 263.

Ropes, M. W., Bennett, G. A., Cobb, S., Jacox, R., and Jessar, R. A. (1956). Bull. rheum. Dis., 7, 121.

$\longrightarrow,-,,-,-(1957)$. Ann. rheum. Dis., $16,118$.

,,,,----- (1959). Ibid., 18, 49

Sharp, J., Purser, D. W., and Lawrence, J. S. (1958). T Ibid., 17, 303. 


\section{Fréquence de l'arthrite rhumatismale \\ RÉSUMÉ}

Pour déterminer la fréquence de l'arthrite rhumatismale, on a examiné du point de vue physique, radiologique et sérologique deux échantillons de la population prise au hasard, l'un composé de 751 hommes et 814 femmes de la ville de Leigh en Lancashire et l'autre de 485 hommes et $540 \mathrm{femmes}$ de Wensleydale en Yorkshire. L'examen a été complet en $86 \%$ de l'échantillon de Leigh et en $87 \%$ de celui en Wensleydale.

En appliquant les critères diagnostiques de la American Rheumatism Association on a trouvé que la fréquence minime de la maladie "définie" était de $0,4 \%$ parmi les hommes at de 1,4\% parmi les femmes, et la fréquence de la maladie "probable" était de $1,7 \%$ parmi les hommes et de 3,8\% parmi les femmes.

On a noté des signes radiologiques d'arthrite érosive chez $8 \%$ des hommes et des femmes radiographiés, mais la maladie était plus grave chez les femmes. Les lésions radiologiques les plus fréquentes se trouvaient dans la colonne cervicale. La réaction d'agglutination des globules de mouton était positive chez $4 \%$ des hommes et chez $5 \%$ des femmes.

On estime qu'au Royaume Uni, en 1959, à peu près 377.000 hommes et 1.034 .000 femmes souffraient d'une arthrite rhumatismale "probable" ou "définie".

\section{Incidencia de artritis reumatoide}

SUMARIO

Para determinar la incidencia de la artritis reumatoide se estudiaron clínica, radiológica y serológicamente dos muestras de población tomadas al azar, una compuesta de 751 varones y 814 mujeres de la ciudad de Leigh en Lancashire y la otra de 485 varones y 540 mujeres de Wensleydale en Yorkshire. La investigación se llevó a cabo en su totalidad en el 86 por ciento de la muestra procedente de Leigh y en el 87 por ciento de la procedente de Wensleydale.

Empleando los criterios diagnósticos de la American Rheumatism Association, la incidencia mínima de enfermedad "definitiva" fué $0.4 \%$ entre varones y $1,4 \%$ entre mujeres, y la incidencia de enfermedad "probable" fué $1,7 \%$ entre varones y $3,8 \%$ entre mujeres.

Evidencia radiológica de artritis erosiva apareció en el $8 \%$ de los sujetos de ambos sexos examinados por este medio, pero la enfermedad era más grave entre las mujeres. Las alteraciones se detectaron con mayor frecuencia en la columna cervical. La reacción de aglutinación de los eritrocitos de carnero fué positiva en el $4 \%$ de los varones y el $5 \%$ de las mujeres.

Se estima que en el Reino Unido en 1959, aproximadamente 377.000 hombres y 1.034 .000 mujeres padecían de "probable" o "definitiva" arthritis reumatoide. 